\title{
Measuring the Customer Perceived Service Quality for Life Insurance Services: An Empirical Investigation
}

\author{
Dr. Masood H Siddiqui (Corresponding Author) \\ Faculty- Decision Sciences, Jaipuria Institute of Management \\ Vineet Khand, Gomtinagar, Lucknow-226010, India \\ Tel: 91-522-2394296 Fax: 91-522-2394295Ｅ-mail: mhsiddiqui@gmail.com \\ Tripti Ghosh Sharma \\ Faculty- Marketing \\ Academy of Business and Engineering Sciences-IT Group of Institutions \\ Vijaynagar, Ghaziabad, India \\ E-mail: tgsharma@gmail.com,tg.sharma@abes.in
}

\begin{abstract}
Liberalization of the financial services sector has led to insurance companies functioning increasingly under competitive pressures; so companies are consequently directing their strategies towards increasing customer satisfaction and loyalty through improved service quality. The present study strives to develop a valid and reliable instrument to measure customer perceived service quality in life-insurance sector. The resulting validated instrument comprised of six dimensions: assurance, personalized financial planning, competence, corporate image, tangibles and technology. Further the results of analytical hierarchy process highlighted the priority areas of service instrument with assurance is the best predictor, followed by competence and personalized financial planning. The gap scores show that there is ample room for improvement in all the aspects related to service quality. These results would help the service managers to efficiently allocate attention and resources among these dimensions on the differential basis, consistent with the customer priorities. These findings can be transformed into effective strategies and actions for achieving competitive advantage through customer satisfaction and retention.
\end{abstract}

Keywords: Service Quality, Life Insurance services, Service quality dimensions, Exploratory factor analysis, GAP analysis, Analytical hierarchy process

\section{Introduction}

With the liberalization and internationalization in insurance, service quality has become an important means of differentiation and path to achieve business success. Such differentiation based on service quality can be a key source of competitiveness for insurance companies and hence have implication for leadership in such organizations.

With the increasing demands of customer, insurance sector has become competitive. The one for all or all for one syndrome is being given a go- by. Customers are becoming increasingly aware of their expectations, and demand higher standards of services, as technology is enabling them to make comparisons quickly and accurately. Their perceptions and expectations are continually evolving, making it difficult for service providers to measure and manage services effectively.

The trend of insurance companies shifting from a product-focused view to a customer-focused one has been developing recently as insurance products become increasingly hard to differentiate in fiercely competitive markets. Insurance companies in India are consequently directing their strategies towards increasing customer satisfaction and loyalty through improved service quality. It is becoming desirable for insurance companies to develop a customer centric approach for future survival and growth. The awareness has already dawned that prompt, efficient and speedy service alone will tempt the existing customers to continue and induce new customers to try the services of the company.

In the life insurance sector, most of the companies have equivalent offerings. Service marketers have realized over past few years that competition can be well managed through quality. Thus service quality is imperative to achieve competitive advantage. Poor quality places a firm at a competitive disadvantage. Service quality offers a way of achieving success among competing services, particularly in case of firms that offer nearly identical services, such as life insurance, where establishing service quality may be the only way of differentiating oneself. 
Such differentiation can yield a higher proportion of consumer's choices, and hence mean the difference between financial success and failure.

\section{Theoretical Observations}

Over the past few years, there has been a considerable research on different aspects of service quality leading to a sound conceptual base for both practioners and researchers. Authors (Parasuraman et al., 1988; 1991; Carman, 1990) agree that service quality is an abstract concept, difficult to define and measure. Some of the contemporary definitions of service quality are summarized in Table 1. On service quality modeling, Gronroos (1984) divides the customer's perceptions of any particular service into two dimensions, namely technical and functional quality. Parasuraman et al. (1985) proposed the gap model of service quality that operationalised service quality as the gap between expectation and performance perception of the customer.

Later on, service quality has also been defined broadly as 'consumers' assessment of the overall excellence or superiority of the service" (Zeithaml et al., 1993). It is viewed as an attitude or global judgment about the overall excellence of a service, with comparison of expectations and performance as the measuring tools. Researchers have tried to operationalize service quality from different perspectives for different service applications. Based on their conceptual and empirical studies, researchers derived and proposed different service quality dimensions for various service applications, as illustrated in Table 2.

However, the most widely used service quality measurement tools include SERVQUAL (Parasuraman et al., 1988; Boulding et al., 1993) and SERVPERF (Cronin and Taylor, 1992). SERVQUAL scale measures service quality, based on difference between expectation and performance perception of customers using 22 items and five-dimensional structure. In the SERVPERF scale, service quality is operationalised through performance only score based on the same 22 items and five dimensional structure of SERVQUAL.

\subsection{Service quality in Life Insurance}

Life insurance providers offer services that are credence products with very few cues to signal quality. It has been suggested that consumers usually rely on extrinsic cues like brand image to ascertain and perceive service quality (Gronroos, 1984). This factor is especially true for a "pure" service such as insurance, which has minor tangible representations of its quality and is highly relational during most transactions. There is also a lack of price signal in the market due to specialized customer needs and difficulty in comparing prices; thus consumers cannot rely solely on price as an extrinsic cue to signal quality.

The outcomes of life insurance purchase are often delayed, and thus do not allow immediate post-purchase valuation. As such, the consequences of a purchase do not produce an immediate reaction towards overall satisfaction. This situation is more apparent as the future benefits of the "product" purchased are difficult to foresee and take a long time to "prove" its effects (Crosby and Stephens, 1987). Infrequent purchase and "usage" of such credence products by consumers would mean an inability or difficulty in forming service expectations due to limited understanding of and familiarity with the service (Johnston et al., 1984). At the same time, because of the amount of money that is typically invested in an insurance policy, customers seek long-term relationships with their insurance companies and respective agents in order to reduce risks and uncertainties (Berry, 1995). Pure services like insurance may, therefore, conjure different expectations than that of services that include tangible products (Toran, 1993). An insurance policy is almost always sold by an agent who, in $80 \%$ of the cases, is the customer's only contact (Richard and Allaway, 1993; Clow and Vorhies, 1993; Crosby and Cowles, 1986). Customers are, therefore, likely to place a high value on their agent's integrity and advise (Zeithaml et al., 1993) The quality of the agent's service and his/her relationship with the customer serves to either mitigate or aggravate the perceived risk in purchasing the life insurance product. Putting the customer first, and, exhibiting trust and integrity have found to be essential in selling insurance (Slattery, 1989). Sherden (1987) laments that high quality service (defined as exceeding "customers' expectations") is rare in the life insurance industry but increasingly demanded by customers.

Toran (1993) points out that quality should be at the core of what the insurance industry does. Customer surveys by Prudential have identified that customer want more responsive agents with better contact, personalized communications from the insurer, accurate transactions, and quickly solved problems (Pointek, 1992). A different study by the National Association of Life Underwriters found other important factors such as financial stability of the company, reputation of the insurer, agent integrity and the quality of information and guidance from the agent (King, 1992). Clearly, understanding consumers' expectations of life insurance agent's service is crucial as expectations serve as standards or reference points against which service performance is assessed (Walker and Baker, 2000).Technology has also become an important factor in how the agent operates in the field including other functions such as distribution, claim costs and administration (Anonymous, 2004). 
Research has shown that the quality of services and the achievement of customer satisfaction and loyalty are fundamental for the survival of insurers. The quality of after sales services, in particular, can lead to very positive results through customer loyalty, positive WOM, repetitive sales and cross-selling (Taylor, 2001). However, many insurers appear unwilling to take the necessary actions to improve their image. This creates problems for them as the market is extremely competitive and continuously becomes more so (Taylor, 2001).

Previous studies, notably those of Wells and Stafford (1995), the Quality Insurance Congress (QIC) and the Risk and Insurance Management Society (RIMS) (Friedman, 2001a, 2001b), and the Chartered Property Casualty Underwriters (CPCU) longitudinal studies (Cooper and Frank, 2001), have confirmed widespread customer dissatisfaction in the insurance industry, stemming from poor service design and delivery. Ignorance of customers' insurance needs (the inability to match customers perceptions with expectations), and inferior quality of services largely account for this. The American Customer Satisfaction Index shows that, between 1994 and 2002, the average customer satisfaction had gone down by $2.5 \%$ for life insurance and $6.1 \%$ for personal property insurance respectively (www.theacsi.org). In Greece, for example, $48 \%$ of consumers consider that the industry as a whole is characterized by lack of professionalism.

It is therefore not surprising that measurement of service quality has generated, and continues to generate, a lot of interest in the industry (Wells and Stafford, 1995). Several metrics have been used to gauge service quality. In the United States, for example, the industry and state regulators have used "complaint ratios" in this respect (www.ins.state.ny.us). The "Quality Score Card", developed by QIC and RIMS, has also been used. However, both the complaints ratios and the quality scorecards have been found to be deficient in measuring service quality and so a more robust metric is needed.

Although service quality structure is found rich in empirical studies on different service sectors, service quality modeling in life insurance services is not adequately investigated. Further, for service quality modeling, a set of dimensions is required, but there seems to be no universal dimension; it needs to be modified as per the service in consideration. Thus, the dimensions issue of service quality requires reexamination in context of life insurance services.

\section{Objective of the Study}

Although numerous researchers have made theoretical and empirical contribution to the study of service quality in various industries, (like banking, healthcare, education etc) the area of life insurance is not adequately researched.

Some previous studies in this area focused exclusively on relational qualities (Crosby and Stephens, 1987) and on the generic SERVQUAL format of quality measurement (Parasuraman et al., 1994).

In the light of this, the objective of this paper is to first investigate service quality structure for life insurance and then relative importance of these service quality dimensions from customers' perspective, so as to ensure optimal deployment of resources among these dimensions, and thereby best value to the customers. Further, the paper tries to measure as to how well services are being delivered i.e. up-to what level performances are meeting the expectations.

A review of literature revealed that the earlier studies on measurement of customer perceived service quality were very few for the life insurance sector, more so in the Indian context. The topic therefore needs to be investigated.

\section{Research Methodology}

In order to develop a reliable and valid service quality measurement scale, an empirical study was undertaken based on methodology shown in Figure 1

We have used Conclusive Cross-sectional Descriptive Research Design to study the service quality structure and its key dimensions in life insurance sector. The survey instrument was a SERVQUAL type questionnaire relevant to insurance industry. The questionnaire was divided into two sections. In the first part information related to different socioeconomic and demographic criteria like income, age, profession, educational qualification, etc was collected. In the second part, respondents were asked to evaluate parameters on service quality relevant to insurance industry (on a 5 point scale anchored at "strongly agree" and "strongly disagree"). This part consists of 26 statements for both expectations and perception scores, regarding various aspects of service quality.

These service quality aspects were identified by a detailed exploratory identification process. This included five focus group discussions (with 40 life insurance policyholders); eight in-depth interviews (three with branch managers and five with agents of various life insurance companies). Content analysis of focus group discussions 
and depth interviews was performed. In content analysis, the responses (oral as well as written) were categorized and classified. Then they are coded for tabulation purpose. Thereafter the frequency counts (of different categories) were compared. The method deployed was qualitative content analysis (inductive category development and deductive category application) (Marying, 2000). These responses were augmented from current literature in order to draw a wider and more in-depth inventory of service quality items in life insurance context. Finally, 26 attributes of service quality in life insurance sector were identified after the process.

A pilot study was conducted with a small sample size of 60 , to clarify the overall structure of questionnaire. The respondents provided comments on clarity of some items and confirmed face validity of items in the questionnaire. These respondents are chosen by shopping mall intercept sampling method. In order to ensure authenticity of the data, the pilot survey was carried out on a wide (demographic) variety of life insurance policyholders.

Quota (multi stage) and shopping mall intercept sampling schemes have been employed with the questionnaires being sent to approximately 1000 respondents (policyholders). However 868 questionnaires were found complete in all respects. The response rate was $86.8 \%$. An attempt has been made to keep the sample fairly representative across the demographic variables by constructing quotas according to various demographic characteristics, discussed above (Table 3).

The areas of our sampling are various cities like Lucknow, Delhi, Mumbai, Bangalore and Kolkata. The time frame of the study was December 2008 to May 2009.

Primary- stage sampling units were the respondents who purchased at least one life insurance product in the last three years from any agent and the exact product purchased should have been either a whole life insurance policy and/or an endowment policy. The secondary stage sampling units were markets, shopping malls, institutions and localities of the above mentioned cities. The questionnaires were administered personally to ensure the authenticity of information provided by the respondents.

\subsection{Validity Analysis}

Content validity: For the present study, the content validity of the instrument was ensured as the service quality dimensions and items were identified from the literature and exploratory investigations, and were thoroughly reviewed by professionals and academicians.

\subsection{Reliability Analysis}

We examined the reliability of the data to check whether random error causing inconsistency and in turn lower reliability is at a manageable level or not, by running reliability test. For various set of important associated factors used in the questionnaire, values of coefficient alpha (Cronbach's alpha) have been obtained. Amongst the reliability tests that were run, the minimum value of coefficient alpha (for both expectations and performance scores) obtained was 0.714 (Table 4), (substantially higher than 0.6 ) which shows that data has satisfactory internal consistency reliability.

\section{Analysis and Results}

Data collected were analyzed through a series of validated tools and procedures. The results of the analysis are described in the following sub sections:

\subsection{Exploratory factor analysis}

\subsubsection{Expectation scores}

In order to explore the underlying dimensions of consumer expectations of service quality vis-à-vis life insurance sector (as expressed by expectation scores on 26 statements), exploratory factor analysis was performed. The factor analysis results are shown in Tables 5.1, 5.2, and 5.3. The results from Table 5.1 shows that value of KMO statistic is very high (.955) and Bartlett's test of Sphericity is significant (sig=.000), which reveals that data is appropriate for factor analysis. The total variance shown in this Table, accounted for by all of the six components explains nearly 78.3 per cent of the variability in the original 26 variables (Table 5.1). So, we can reduce the original dataset by using these six components (Eigen values greater than 1 as shown in Table 5.1.) with only 21 per cent loss of information.

The Rotated Component Matrix reveals six factors (which represent the six broad perceptual dimensions of service quality) derived from 26 variables (which represent the expectations of life insurance policy-holders vis-à-vis service quality). The components of each factor have been highlighted in Table 5.3.

Factor 1 incorporates the variables- "Trained and well-informed agents", "Approaching from customer's point of view", "Trusting agents when explaining policies", "Clarity in explaining policy's terms and conditions" and 
"Understanding intimately specific needs". Since all these variables assure the policyholder of knowledge of agents and their ability to inspire trust and confidence, this factor was labeled as 'assurance.'

Factor 2 has variables- "Provision of Flexible payment schedule", "Availability of flexible product solution", "Provisions for Convertibility of products", "Supplementary services". Life insurance involves long term association, hence policyholder moves through different life cycle stages in this long period and his needs and preferences change accordingly. Here, all these variables are depicting handling of these changing preferences, by providing flexible solutions and convertibility options and giving personalized services. So, this factor can be labeled as 'personalized financial planning'.

Factor 3 has variables- "Staff dependable in handling customer's problems", "Efficient staff", "Easy access to information", "Prompt \& Efficient Grievance handling mechanism" and "Prompt and hassle free claims settlement". Since these components talk about the ability of the service provider to perform service dependably and efficiently and also about their willingness to provide hassle-free and prompt services. So, this factor can be labeled as 'competence'.

Factor 4 has variables- "Adequate No. of branches", "Accessible location of the branch", "Good ambience of the branch", and "Possessing good certification and credentials". Since all these components are related to providing physical facilities and communication materials. So, this factor can be labeled as 'tangibles'.

Factor 5 has variables- "Innovativeness in introducing new products", "Courteous Agents", "Value for money", "Simple and Less time consuming Procedure for purchasing a policy", and "Financially stable company". Since all these components are related to creating an overall image of the organization in the eyes of the customers. So, this factor can be labeled as 'corporate image'.

Factor 6 has variables- "Easy online transaction", "Prompt complaint handling, online", and "Proactive information through e-mail or SMS". Since all these components are related to use of modern aids in providing service. So, this factor can be labeled as 'technology'.

\subsubsection{Performance scores}

As with Expectation scores, for explaining the underlying dimensions of consumer perceptions of service quality vis-à-vis life insurance sector (as expressed by performance scores on 26 statements), exploratory factor analysis was again performed. The factor analysis results are shown in Tables 6.1, 6.2, and 6.3. The results from Table 6.1 shows that value of KMO statistic is very high (.946) and Bartlett's test of Sphericity is significant $(\mathrm{sig}=.000)$, which reveals that data is appropriate for factor analysis. The total variance shown in this Table, accounted for by all of the three components explains nearly 62.2 per cent of the variability in the original 26 variables (Table 6.2). So, we can reduce the original dataset by using these six components (Eigen values greater than 1 as shown in Table 6.3) with 38 per cent loss of information.

The Rotated Component Matrix reveals the same set of six factors (which represent the six broad perceived dimensions of service quality) derived from 26 variables (which represent the perception of policyholders with respect to services being delivered). The components of each factor have been highlighted in Table 6.3.

\subsection{Prioritization of Service Quality Dimensions}

Life insurance is a professional service which is characterized by high involvement of the consumers due to the importance of tailoring specific needs, the variability of products available, the complexity involved in the policies and processes and the need to involve consumer in every aspect of the transaction. All these characteristics cause the customer to seek long term relationships with their insurance agents, their service providers, in order to reduce risks and uncertainties (Berry, 1995).

Since there is such a high involvement of customers and since the associated risks are so high, it becomes imperative for the service provider to understand how sensitive the customers are to various dimensions of service quality. This would decide the deployment of resources among these dimensions so that best value is provided to the customers. The service attribute that is valued higher by the customers must be given attention and resource support more than less valued ones.

The data collected from the sample was analyzed, so as to prioritize dimensions of service Quality, using qualitative analysis tool Analytic Hierarchy Process (AHP). AHP, developed by Saaty (1990; 2001), is designed for situations in which ideas, feelings and emotions are to be quantified and decision alternatives based on them are prioritized. It develops a hierarchical structure of the decision alternatives based on the relative importance placed on each criterion as well as the rating of each alternative on each criterion. AHP is used due to its suitability for undertaking quantitative as well as qualitative analysis. This approach differs from other 
multi-criteria methods as subjective judgments are readily included and any inconsistencies are dealt with appropriately. The collected data was analyzed using Expert-Choice 11.0 Software.

The weights of each factor (representing the relative importance of service quality attribute) are used to rank the decision alternatives, providing their relative importance. Results (as obtained from AHP) revealed that there is a hierarchy of service quality factors, with assurance as the most important factor, followed by competence, personalized financial planning, corporate image, tangibles and technology (Figure2).

Customers perceive assurance (with a relative weight of 36\%) as the most important dimension of overall expectations of service-quality. This finding makes sense because insurance represents a huge investment and customers evaluate highly those agents who are perceived to be trustworthy and make customers feel assured that they made the correct decision. In the personalized selling process of whole life insurance, Loo (2000) cited the views of industry observers and experts that insurance products are a very personal matter where people enjoy the comfort of talking to experts who are knowledgeable on insurance. Moreover, the nature of the products was described as varied, making it difficult to judge the appropriateness of the products and creating a preference to talk to someone when a claim arises. These ideas confirm the critical role of the agent-policyholder relationship and the role of assurance in that relationship. Assurance implies that the agent will be prepared to deliver on the terms of the life insurance policy when it is redeemed. Next to assurance, competence (relative weight $=26 \%$ ) and personalized financial planning (relative weight $=20 \%$ ) were perceived to be the next important dimensions of service quality expectations. Competence implies that the agent will be prepared to deliver on the terms of the life insurance policy when it is redeemed. Competence also means that the customer can count on the agent to resolve any problems should they arise, and that too promptly and efficiently. Personalized financial planning implies that the agent is prepared to restructure the policies as per the changing needs of the customer (like providing information about convertibility of products, flexible payment and product solutions).

They were followed by corporate image (relative weight $=9 \%$ ) at the fourth place of the hierarchy. The lowest place in the hierarchy was taken by tangibles (relative weight $=5 \%$ ) and technology (relative weight $=4 \%$ ).

\subsection{GAP analysis}

Gap analysis (Gap 5 = perception minus expectation) was performed to measure the service quality in life insurance industry. In services, quality is measured by the perception of the customer on how well the service has been delivered (Hampton, 1993; Lewis, 1983). It is important to test the policyholders' perceptions (actual experience) to see whether the service quality provided by the life insurance industry was meeting, exceeding or falling below the expectations. In turn, it can also be a measurement of satisfaction/dissatisfaction with the delivery of services. Therefore, the study of Gap 5 can be a useful tool for management in monitoring the service delivery in life insurance industry.

The results revealed that in all the service quality dimensions of life insurance industry in India the gap-scores are negative and for each of six factors, the gap scores were statistically significant (sig. <.05) (Table 7). This can be interpreted as a gap between what was expected and perceived, thus indicating a failure in service delivery and service quality at all the levels vis-à-vis life insurance industry in India.

Analyzing the 'gaps', we can conclude that insurers have the opportunity to take the appropriate actions to improve the quality of their services, giving priority to factors with the largest gap scores. We can say that there are gaps in all the dimensions so there is room for improvement in all the aspects of service quality in life insurance industry.

The maximum gap in competence dimension reiterates the deficiencies in delivery of promised services during claims settlement, and in general, in handling customer problems. Also there are large differences in performance and expectation levels in the dimensions of personalized financial planning and corporate image. It reflects wide dissatisfaction regarding non delivery of personalized attention to the varied and changing needs of policyholders as well as not being able to prove as value for money, innovative or financially stable company. Prioritized deployment of resources to these dimensions is necessary to accomplish the desired results.

\section{Discussion and Managerial Implication}

The most important aspect of the relationship between service providers and customers is that the service providers lack an in-depth insight into customer preferences. Often there is a disconnect between what customers want and what service providers offer. This is particularly true in case of services like life insurance because of the intangibility element associated with it. The present study has been undertaken to first identify the various attributes of service quality construct with respect to life insurance industry and then to determine hierarchical framework of these attributes as perceived by customers. 
The present study attempts to develop an instrument to measure customer perceived service quality in life insurance sector. Accordingly, a six dimensional instrument comprising of assurance, personalized financial planning, competence, corporate image, tangibles and technology is suggested. Undeniably, the factors have many elements of the old SERVQUAL dimensions except the technology dimension. However, this is expected, as the SERVQUAL instrument has undergone rigorous testing and serves as an important platform for exploratory contextual investigations in Service Quality measurement. Emergence of Technology as a factor clearly indicates towards the growing sophistication of customers.

Further the results of Analytical Hierarchy Process highlight the priority areas of service improvement and reveal that not all dimensions contribute equally to overall expectations of service quality in life insurance context i.e. there is a hierarchy of service quality factors in this industry.

The study indicates that among the various service quality dimensions in the life insurance industry, assurance is the most important determinant of service quality, followed by personalized financial planning, competence, corporate image, tangibles and technology, in that order.

Hence the Life Insurance companies needs to comprehend assurance in customer terms and deliver the same. The life insurance policyholders have primarily defined assurance in terms of well trained and informed agents, who understand intimately specific needs, approach from customer's point of view show clarity in explaining policy's terms and conditions and thereby inspire trust and confidence. Therefore, it is imperative for the service providers to provide adequate training to their agents to improve their customer interaction skills and knowledge.

Additionally, competence factor, as the second most important determinant, appeared to play an important role in influencing the overall service quality as expected by the customer. Within the purview of this attribute the policyholders accorded the highest priority to 'efficient claims settlement'. Beyond this, the service providers need to focus on promptness in 'grievance handling', that too by efficient and dependable staff. This implies that life insurance providers should invest in empowering the agents and employees with adequate resources so that they can take prompt actions.

Thereafter at the third place in the worth hierarchy is the attribute of personalized financial planning. Customers of life insurance policies seek personalized services and constant support in financial planning e.g. flexible payment schedule, flexible product solution, provisions for convertibility of products and supplementary services etc. So, service providers should encourage the agents to assume wider roles, that of financial consultants.

The corporate image is at the fourth place in the overall rating of the service quality dimensions. In this case, it is imperative for the service providers to focus on having courteous agents who represent a financially stable company, on being innovative in introducing new products, and in general proving to be value for money in the long run.

In the hierarchical preference structure of service quality instrument, tangibles and technology dimensions are at the lowest place, but these factors may also contributes towards satisfaction/dissatisfaction with the services.

Regarding tangibles, it is required that service providers should have good certification and credentials and adequate number of accessible branches. This is more important than investing large sums of money for creating magnificent structures alone. There is need, therefore for insurers to rethink their strategies in this aspect.

Technology is the new dimension identified in this study. In this case, service providers should focus on ensuring ease of online transaction, prompt complaint handling, online and availability of proactive information through e-mail or SMS.

From the management perspective, the study provides information on service quality dimensions and their relative importance to the service providers in life insurance industry. This information can be used by service providers for adding value to their relationship with the current and prospective policyholders, by performing on differential strategies aimed at improving the service quality in this sector. Thus the service providers are required to focus more on important dimensions to achieve high level of service quality and also aim at reaching acceptable limits for not so important dimensions.

Results from the gap analysis indicate that there is much to be done with respect to service quality in this industry. Insurers have the opportunity to take the appropriate actions to improve the quality of their services, giving priority to factors with the largest gap scores. On these grounds, insurers should deal with competence, personalized financial planning, corporate image, assurance, tangibles, technology in that order, since this is the order of decreasing gap scores. A sound quality improvement strategy for the individual companies should focus on fixing quality flaws in the same order. 
In the life insurance industry, perception of service on the competence, personalized financial planning and corporate image dimensions is largely below that of expectation level. This finding is clearly disturbing since these dimensions have strong correlation with expectations of quality. Clearly, if some customers feel that they are not getting personalized services for planning their finances or if the feel that their company is not competent enough or if they feel that they are not getting value for money or have to deal with inefficient agents, such customers will defect.

The decision making authorities in the life insurance companies can also assess the gaps provided by the study, to appropriately bridge them by developing corrective action plans. Such corrective actions will ensure greater customer satisfaction as well as a differentiable competitive advantage.

It is very clear from the above discussions that insurers have to shed a lot of old ideas, bring changes in practices, and adopt a distinct approach to meet the challenges of the emerging situation ahead. Hence it is desirable for insurance companies to develop a customer centric approach for future survival and growth.

The major managerial implications of the study include the following:

- The service quality instrument so developed can be used by the managers for periodic monitoring of service quality as perceived by the customers.

- The study also provides directions to service providers as to which particular dimensions require attention in terms of their importance. This would enable the service providers to focus resources in accordance with the importance of these dimensions.

- Further, the study helps the service providers to identify quality gaps in the industry and thereby helps them in devising strategies, so as to plug these.

\section{Conclusions}

The research resulted in the development of a reliable and valid instrument for assessing customer perceived service quality for life insurance services. Here, service quality needs to be measured using a six dimensional hierarchal structure consisting of assurance, competence, personalized financial planning, corporate image, tangibles and technology dimensions. This would help the service managers to efficiently allocate resources, by focusing on important dimensions first. The gap scores show that there is ample room for service quality improvement in life insurance industry in India. In the competitive insurance sector, these findings can be transformed into effective strategies and actions for achieving competitive advantage through customer satisfaction and retention.

Although this study focuses on life insurance industry in India, however the results and recommendations of this paper can be used for service quality improvements of life insurance industries of other countries as well. This can be performed by incorporating necessary changes in service quality aspects in accordance with socio-economic environment of that nation.

There are, some scope for further research. Future studies in this area should also measure changes in service quality expectations over time in order to have a better understanding of how perceptions about service quality relate to satisfaction and loyalty. This is because service expectations and perceptions are known to be affected by customers' immediate reaction to specific service encounters. Cross-sectional studies that measure service expectations at one point in time may understate or overstate true service expectations, depending on whether customers had a positive or negative experience with the service provider.

The usefulness of segmenting customers on the basis of demographics is worth exploring. A future research aimed at determining whether distinct, identifiable service quality segments exist on the basis of customer demographics will be valuable from a service marketer's viewpoint. Insight from customer surveys or even more informal means of research could be used as a valuable information base in this regard.

The study can be further extended to investigate the causal relationship between service quality, customer satisfaction, loyalty and retention. Such a study would enhance the level of understanding for managers and academicians.

\section{References}

Anonymous. (2004). Seizing the initiative. Life Insurance International, April, 11-12.

Asubonteng, P., McCleary, K. J. \& Swan, J. E. (1996). SERVQUAL Revisited: A Critical Review Of Service Quality. Journal of Services Marketing, 10(6), 62-81.

Berry, L. L. (1995). Relationship marketing of services-growing interest, emerging perspectives. Journal of the Academy of Marketing Science, 23 (Fall), 236-245. 
Bitner, M. J., Booms, B. H. \& Tetreault, M. S. (1990). The Service Encounter: Diagnosing Favourable and Unfavourable Incidents. Journal of Marketing, 54(1), 71-84.

Boulding, W., Karla, A., Staelin, R. \& Zeithaml, V. A. (1993). A Dynamic Process Model of Service Quality: From Expectations to Behavioural Intentions. Journal of Marketing Research, 30(1), 7-27.

Carman, J. M. (1990). Consumer Perceptions of Service Quality: An Assessment of the SERVQUAL Dimensions. Journal of Retailing, 66 (Spring), 33-55.

Clow, K. F. \& Vorhies, D. W. (1993). Building a Competitive Advantage for Service Firms. Journal of Services Marketing, 7(1), 22-32.

Cooper, R. W. \& Frank, G. L. (2001). Key ethical issues facing the property and casualty insurance: has a decade made a difference? CPCU Journal, 54 (2), 99-111.

Cronin, J. J. Jr. \& Taylor, S. A. (1992). Measuring Service Quality: A Reexamination and Extension. Journal of Marketing, 56 (3), 55-68.

Crosby, L. A. \& Cowles, D. (1986). Life Insurance Agents as Financial Planners: A Matter of Role Consensus. Journal of Professional Services Marketing, 1 (Spring), 69-89.

Crosby, L. A. \& Stephens, N. (1987). Effects of relationship marketing on satisfaction, retention, and prices in the life insurance industry. Journal of Marketing Research, 24(November), 404-411.

Friedman, S. (2001b). RIMS launches quality process. National Underwriter, 105(19), 3-29.

Friedman, S. (2001a). RIMS plans to have third quality scorecard published in 2002. National Underwriter, 105(18), 3-22.

Gronroos, C. (1984). A service-oriented approach to marketing of services. European Journal of Marketing, 12 (8), 588-601.

Hampton, G. M. (1993). Gap Analysis of College Student Satisfaction as a Measure of Professional Service Quality. Journal of Professional Services Marketing, 9(1), 15-28.

Johnson, R. L., Tsiros, M. \& Lancioni, R. A. (1995). Masuring Service quality: A Systems approach. Journal of Services Marketing, 9 (5), 6-19.

Johnston, E. O., O'Connor, R. J. \& Zultowski, W. H. (1984). The personal selling process in the life insurance industry, in J. Jacoby, \& C. S. Craig (Eds.), Personal Selling: Theory, Research and Practice (pp. 136-164). Lexington, MA: Lexington Books.

King, C. (1992). Agents/policy owners split on service. National Underwriter, 41(October), 7.

Lehtinen, U. \& Lehtinen, J. R. (1991). Two Approaches to Service Quality Dimensions. The Service Industries Journal, 11(3), 287-305.

Lewis, B. (1993). Service quality: recent developments in financial services. International Journal of Bank Marketing, 11(6), 19-25.

Loo, F. (2000). Buying insurance on the net. Financial Planner, February, 58-60.

Marying, P. (2000). Qualitative Content Analysis. Forum: Qualitative Social Research. 1 (2), Art. 20:June 2000 (www.qualitative-research.net/index.php/fqs/article/.../1089) (Jan 7, 2010).

Mehta, S. C. \& Lobo, A. (2002). MSS, MSA and zone of tolerance as measures of service quality: A Study of the Life Insurance Industry. Second International Services Marketing Conference, University of Queensland.

Parasuraman, A. \& Zeithaml, V. A. \& Berry, L. L. (1985). A Conceptual Model of Service Quality and Its Implications for Future Research. Journal of Marketing, 49(4), 41-50

Parasuraman, A., Berry, L. L. \& Zeithaml, V. A. (1991). Refinement and reassessment of the SERVQUAL scale. Journal of Retailing, 67(4), 420-450.

Parasuraman, A., Zeithaml, V. A. \& Berry, L. L. (1988). SERVQUAL: A Multi-Item Scale for Measuring Consumer Perceptions of Service Quality. Journal of Retailing, 64 (Spring), 21-40.

Parasuraman, A., Zeithaml, V. A. \& Berry, L. L. (1994). Alternatives Scales for Measuring Service Quality: A Comparative Assessment Based on Psychometric and Diagnostic Criteria. Journal of Retailing, 70(3), 201-230.

Pointek, S. (1992). Outside interests: making the move from lip service to real service. National Underwriter, 96 (44), 34. 
Rand, G. K. (2004).Diagnosis and Improvement of Service Quality in the Insurance Industries of Greece and Kenya. Lancaster University Management School Working Paper.

Richard, M. D. \& Allaway, A. W. (1993). Service Quality Atrributes and Choice Behaviour. Journal of Services Marketing, 7(10), 59-68.

Rosen, L. D. \& Karwan, K. R. (1994). Prioritizing the Dimensions of Service quality. International Journal of Service industry Management, 5 (4), 39-52.

Saaty, T. L. (1990). The Analytic Hierarchy Process. Pittsburgh, PA: RWS Publications.

Saaty, T. L. (2001). Decision Making with Dependence and Feedback the Analytic Network Process, $2^{\text {nd }}$ ed. Pittsburgh, PA: RWS Publications.

Seth, A., Momaya, K. \& Gupta, H. M. (2008). Managing the Customer Perceived Service quality for cellular Mobile Telephony: An Empirical Investigation. Vikalpa, 33 (1), 9-34.

Sherden, W. (1987). The erosion of service quality. Best's Review, 88 (5), 22.

Siu, N. Y. M. \& Cheung, J. T. (2001). A Measure of Retail Service Quality. Marketing Intelligence and Planning, 19 (2), 88-96.

Slattery, T. (1989). Special report: Nichols: we've forgotten the consumer. National Underwriter, 48 (November), 11.

Stafford, M. R., Stafford, T. F. \& Wells, B. P. (1998).Determinants of service quality and satisfaction in the auto casualty claims process. Journal of Services Marketing, 12, 426-440.

Taylor, S. A. (2001). Assessing the use of regression analysis in examining service recovery in the insurance industry: relating service quality, customer satisfaction and customer trust. Journal of Insurance Issues, 24 (1/2), 30-57.

Teas, R. K. (1993). Consumer Expectations and the Measurement of Perceived Service Quality. Journal of Professional Services Marketing, 8 (2), 33-54.

Toran, D. (1993). Quality service (quality everything!). LIMRA'S Market Facts, 12 (2), 10-11.

Walker, J. \& Baker, J. (2000). An exploratory study of a multi-expectation framework for services. Journal of Services Marketing, 14 (5), 411-431.

Wells, B. P. \& Stafford, M. R. (1995). Service quality in the insurance industry: Consumer perceptions versus regulatory perceptions. Journal of Insurance Regulation, 13, 462-477.

Zeithaml, V. A., Berry, L. L. \& Parsuraman, A. (1993). The Nature and Determinants of Customer Expectations of Service. Journal of the Academy of Marketing Science, 21(1), 1-12.

Table1. Select definitions of Service Quality

\begin{tabular}{|l|l|l|}
\hline S.No. & Author,Year & Definitions \\
\hline 1. & Parasuraman, Zeithaml and Berry, 1988 & Global judgement or attitude, relating to superiority of service. \\
\hline 2. & Bitner, Booms and Tetreauly,1990 & $\begin{array}{l}\text { The customer's overall impression of the relative inferiority/superiority of } \\
\text { the organization and its services. }\end{array}$ \\
\hline 3. & Asubonteng, McCleary and Swan, 1996 & $\begin{array}{l}\text { The difference between customer's expectations for service performance } \\
\text { prior to the service encounter and their perceptions of the service received. }\end{array}$ \\
\hline
\end{tabular}


Table 2. Select service quality dimensions

\begin{tabular}{|c|c|c|c|c|c|c|}
\hline $\begin{array}{l}\text { Authors } \\
\text { (Year) }\end{array}$ & $\begin{array}{l}\text { Parasuraman, } \\
\text { Zeithaml and Berry } \\
(\mathbf{1 9 8 8 )}\end{array}$ & $\begin{array}{l}\text { Lehtinen and } \\
\text { Lehtinen (1991) }\end{array}$ & $\begin{array}{l}\text { Rosen and } \\
\text { Karwan } \\
(1994)\end{array}$ & $\begin{array}{l}\text { Johnson, } \\
\text { Tsiros and } \\
\text { Lancioni } \\
\text { (1995) } \\
\end{array}$ & $\begin{array}{l}\text { Siu and Cheung } \\
\text { (2001) }\end{array}$ & $\begin{array}{l}\text { Mehta and Lobo } \\
\text { (2002) }\end{array}$ \\
\hline $\begin{array}{l}\text { Application } \\
\text { areas }\end{array}$ & $\begin{array}{l}\text { Telephone co., } \\
\text { brokerage, insurance } \\
\text { co., banks and repair } \\
\text { and maintenance }\end{array}$ & $\begin{array}{l}\text { Lunch restaurants, } \\
\text { Disco, Pub type } \\
\text { restaurants }\end{array}$ & $\begin{array}{l}\text { Teaching, } \\
\text { restaurants, } \\
\text { bookstore } \\
\text { and } \\
\text { healthcare. }\end{array}$ & $\begin{array}{l}\text { Bank customer } \\
\text { UK }\end{array}$ & $\begin{array}{l}\text { Service quality } \\
\text { delivery of a } \\
\text { department store } \\
\text { chain }\end{array}$ & Life Insurance \\
\hline \multirow[t]{7}{*}{ Dimensions } & Reliability & Physical quality & Reliability & Input quality & $\begin{array}{l}\text { Personal } \\
\text { interaction }\end{array}$ & Assurance \\
\hline & Responsiveness & Corporate quality & $\begin{array}{l}\text { Responsiven } \\
\text { ess }\end{array}$ & Output quality & Policy & $\begin{array}{l}\text { Personalised } \\
\text { financial planning }\end{array}$ \\
\hline & Assurance & Interactive quality & Tangibles & Process quality & $\begin{array}{l}\text { Physical } \\
\text { appearance }\end{array}$ & $\begin{array}{l}\text { Similarity with } \\
\text { Agent }\end{array}$ \\
\hline & Empathy & Process quality & Access & & Promises & Tangibles \\
\hline & & & & & & Competence \\
\hline & \multirow[t]{2}{*}{ Tangibles } & \multirow[t]{2}{*}{ Output quality } & $\begin{array}{l}\text { Knowing the } \\
\text { customer }\end{array}$ & & Problem solving & \multirow[t]{2}{*}{ Corporate Image } \\
\hline & & & Assurance & & Convenience & \\
\hline
\end{tabular}

Table 3. Demographic Characteristics of the Respondents:

\begin{tabular}{|l|l|l|}
\hline S. No. & Respondent's characteristics & \% of respondents \\
\hline 1 & Gender & \\
\hline & Male & 60.4 \\
\hline 2 & Female & 39.6 \\
\hline & Age Group & \\
\hline & $<30$ & 27.6 \\
\hline & $31-45$ & 50.7 \\
\hline & $46-60$ & 13.8 \\
\hline 3 & $>60$ & 7.8 \\
\hline & Education & \\
\hline & Upto HSC & 9.4 \\
\hline & Graduate & 35.0 \\
\hline & Post graduate & 35.9 \\
\hline 4 & Professional and others & 19.6 \\
\hline & Occupation & \\
\hline & Salaried & 41.2 \\
\hline & Professional & 27.8 \\
\hline & Business & 13.1 \\
\hline & Student & 2.8 \\
\hline & Retired & 7.4 \\
\hline 5 & Housewife & 6.9 \\
\hline & Income & \\
\hline & $<10,000$ & 11.8 \\
\hline & $10001-20000$ & 15.0 \\
\hline & $20001-30000$ & 34.6 \\
\hline & $30001-40000$ & 23.0 \\
\hline 6 & $>40000$ & 15.7 \\
\hline & Access to modern aids & \\
\hline & Mobile-phone & 57.6 \\
\hline & Internet & 13.8 \\
\hline & Combination & 13.4 \\
\hline & & \\
\hline & & \\
\hline & & \\
\hline & & \\
\hline & & \\
\hline & & \\
\hline & & \\
\hline & & \\
\hline & & \\
\hline & &
\end{tabular}


Table 4. Reliability Analysis

\begin{tabular}{|l|l|l|l|}
\hline Dimensions of Service Quality & $\begin{array}{l}\text { No. of } \\
\text { Items }\end{array}$ & $\begin{array}{l}\text { Expectation (Cronbach's } \\
\text { alpha) }\end{array}$ & $\begin{array}{l}\text { Perception (Cronbach's } \\
\text { alpha) }\end{array}$ \\
\hline Assurance & 5 & .821 & .880 \\
\hline Competence & 4 & .934 & .904 \\
\hline Personalized financial planning & 5 & .789 & .823 \\
\hline Corporate image & 4 & .882 & .845 \\
\hline Tangibles & 5 & .811 & .776 \\
\hline Technology & 3 & .714 & .743 \\
\hline
\end{tabular}

Table 5.1. KMO and Bartlett's Test

\begin{tabular}{|l|l|r|}
\hline Kaiser-Meyer-Olkin Measure of Sampling Adequacy. & .955 \\
\hline Bartlett's Test of Sphericity & Approx. Chi-Square & 10568.886 \\
\hline & Df & 325 \\
\hline & Sig. & .000 \\
\hline
\end{tabular}

Table5.2. Total Variance Explained

\begin{tabular}{|c|c|c|c|c|c|c|c|c|c|}
\hline Component & Initial & igenvalues & & Extracti & n Sums of Sc & ared Loadings & Rotation & Sums of Squared & oadings \\
\hline & Total & $\begin{array}{l}\% \text { of } \\
\text { Variance }\end{array}$ & Cumulative \% & Total & $\begin{array}{l}\% \text { of } \\
\text { Variance }\end{array}$ & Cumulative \% & Total & $\begin{array}{l}\% \text { of } \\
\text { Variance }\end{array}$ & Cumulative \% \\
\hline 1 & 13.65 & 52.501 & 52.501 & 13.65 & 52.501 & 52.501 & 8.198 & 31.532 & 31.532 \\
\hline 2 & 3.329 & 12.803 & 65.305 & 3.329 & 12.803 & 65.305 & 5.887 & 22.644 & 54.176 \\
\hline 3 & 1.434 & 5.515 & 70.82 & 1.434 & 5.515 & 70.82 & 2.173 & 8.358 & 62.534 \\
\hline 4 & 0.774 & 2.976 & 73.796 & 0.774 & 2.976 & 73.796 & 1.961 & 7.542 & 70.076 \\
\hline 5 & 0.63 & 2.422 & 76.218 & 0.63 & 2.422 & 76.218 & 1.19 & 4.575 & 74.651 \\
\hline 6 & 0.548 & 2.106 & 78.324 & 0.548 & 2.106 & 78.324 & 0.955 & 3.673 & 78.324 \\
\hline 7 & 0.513 & 1.974 & 80.299 & & & & & & \\
\hline 8 & 0.496 & 1.906 & 82.205 & & & & & & \\
\hline 9 & 0.459 & 1.765 & 83.97 & & & & & & \\
\hline 10 & 0.394 & 1.514 & 85.484 & & & & & & \\
\hline 11 & 0.391 & 1.503 & 86.987 & & & & & & \\
\hline 12 & 0.376 & 1.444 & 88.431 & & & & & & \\
\hline 13 & 0.359 & 1.382 & 89.813 & & & & & & \\
\hline 14 & 0.333 & 1.28 & 91.093 & & & & & & \\
\hline 15 & 0.324 & 1.245 & 92.339 & & & & & & \\
\hline 16 & 0.282 & 1.086 & 93.425 & & & & & & \\
\hline 17 & 0.262 & 1.009 & 94.434 & & & & & & \\
\hline 18 & 0.251 & 0.967 & 95.401 & & & & & & \\
\hline 19 & 0.227 & 0.874 & 96.275 & & & & & & \\
\hline 20 & 0.209 & 0.806 & 97.081 & & & & & & \\
\hline 21 & 0.163 & 0.627 & 97.708 & & & & & & \\
\hline 22 & 0.157 & 0.605 & 98.314 & & & & & & \\
\hline 23 & 0.127 & 0.49 & 98.804 & & & & & & \\
\hline 24 & 0.113 & 0.433 & 99.237 & & & & & & \\
\hline 25 & 0.107 & 0.412 & 99.649 & & & & & & \\
\hline 26 & 0.091 & 0.351 & 100 & & & & & & \\
\hline
\end{tabular}


Table 5.3. Rotated Component Matrix (a)

\begin{tabular}{|c|c|c|c|c|c|c|}
\hline & \multicolumn{6}{|c|}{ Component } \\
\hline & 1 & 2 & 3 & 4 & 5 & 6 \\
\hline Adequate No. of branches & .219 & .277 & .304 & .707 & .213 & .153 \\
\hline Trained and well-informed agents & .758 & .397 & .163 & .276 & .065 & .256 \\
\hline Approaching from customer's point of view & .683 & .459 & .182 & .193 & .012 & .133 \\
\hline Accessible location of the branch & .228 & .374 & .025 & .704 & .052 & .122 \\
\hline Staff dependable in handling customer's problems & .234 & .217 & .739 & .237 & .105 & .184 \\
\hline Good ambience of the branch & .232 & .404 & .453 & .685 & .214 & -.062 \\
\hline Efficient Staff & .220 & .239 & .688 & .197 & .356 & -.028 \\
\hline Easy access to information & .218 & .204 & .851 & .158 & -.042 & .201 \\
\hline Provision of Flexible payment schedule & .270 & .768 & .225 & .187 & -.153 & .022 \\
\hline Innovativeness in introducing new products & .245 & .184 & .223 & .210 & .697 & .067 \\
\hline Possessing good certification and credentials & .211 & .093 & .143 & .617 & .478 & .127 \\
\hline Courteous Agents & .223 & .250 & .445 & .374 & .787 & .211 \\
\hline Value for money & .210 & .418 & .437 & .264 & .640 & -.052 \\
\hline Availability of flexible product solution & .218 & .845 & .079 & .049 & .082 & .029 \\
\hline Provisions for Convertibility of products & .274 & .818 & .104 & .070 & .198 & .094 \\
\hline Supplementary services & .459 & .781 & .057 & .062 & -.004 & .080 \\
\hline Prompt \& Efficient Grievance handling mechanism & .014 & .425 & .806 & .115 & -.010 & .095 \\
\hline Simple \& Less time consuming Procedure for purchasing a policy & .082 & .382 & .050 & .119 & .780 & .088 \\
\hline Trusting agents when explaining policies & .854 & .296 & .100 & .112 & .075 & .066 \\
\hline Financially stable company & -.031 & .137 & .166 & -.044 & .792 & .230 \\
\hline Clarity in explaining policy's terms and conditions & .813 & .209 & .166 & .090 & .064 &.- .042 \\
\hline Easy online transaction & -.065 & .187 & .091 & .235 & .049 & .844 \\
\hline Complaint handling should be prompt, online & -.105 & .232 & .107 & .213 & .097 & .851 \\
\hline Proactive information through e-mail or SMS & .034 & .182 & .137 & .171 & .077 & .867 \\
\hline Prompt and hassle free claims settlement & .116 & .016 & .830 & .045 & .229 & .243 \\
\hline Understanding intimately specific needs & .796 & .053 & .129 & .115 & .285 & .102 \\
\hline
\end{tabular}

Extraction Method: Principal Component Analysis.

Rotation Method: Varimax with Kaiser Normalization.

Table 6.1. KMO and Bartlett's Test

\begin{tabular}{|l|l|r|}
\hline Kaiser-Meyer-Olkin Measure of Sampling Adequacy. & .946 \\
\hline Bartlett's Test of Sphericity & Approx. Chi-Square & 522.535 \\
\hline & Df & 325 \\
\hline & Sig. & .000 \\
\hline
\end{tabular}


Table 6.2. Total Variance Explained

\begin{tabular}{|c|c|c|c|c|c|c|c|c|c|}
\hline \multirow[t]{2}{*}{$\begin{array}{l}\text { Comp } \\
\text { onent }\end{array}$} & \multicolumn{3}{|c|}{ Initial Eigenvalues } & \multicolumn{3}{|c|}{ Extraction Sums of Squared Loadings } & \multicolumn{3}{|c|}{ Rotation Sums of Squared Loadings } \\
\hline & Total & $\begin{array}{c}\% \text { of } \\
\text { Variance }\end{array}$ & $\begin{array}{c}\text { Cumulative } \\
\% \\
\end{array}$ & Total & $\begin{array}{c}\% \text { of } \\
\text { Variance } \\
\end{array}$ & Cumulative \% & Total & $\begin{array}{c}\% \text { of } \\
\text { Variance }\end{array}$ & $\begin{array}{c}\text { Cumulativ } \\
\mathrm{e} \% \\
\end{array}$ \\
\hline 1 & 10.237 & 39.373 & 39.373 & 10.237 & 39.373 & 39.373 & 3.853 & 14.818 & 14.818 \\
\hline 2 & 2.015 & 7.750 & 47.124 & 2.015 & 7.750 & 47.124 & 3.690 & 14.190 & 29.008 \\
\hline 3 & 1.181 & 4.543 & 51.667 & 1.181 & 4.543 & 51.667 & 3.107 & 11.949 & 40.958 \\
\hline 4 & .973 & 3.741 & 55.407 & .973 & 3.741 & 55.407 & 2.452 & 9.431 & 50.389 \\
\hline 5 & .925 & 3.557 & 58.964 & .925 & 3.557 & 58.964 & 1.944 & 7.476 & 57.864 \\
\hline 6 & .838 & 3.223 & 62.188 & .838 & 3.223 & 62.188 & 1.124 & 4.323 & 62.188 \\
\hline 7 & .775 & 2.980 & 65.168 & & & & & & \\
\hline 8 & .742 & 2.855 & 68.023 & & & & & & \\
\hline 9 & .688 & 2.647 & 70.669 & & & & & & \\
\hline 10 & .660 & 2.537 & 73.207 & & & & & & \\
\hline 11 & .644 & 2.478 & 75.685 & & & & & & \\
\hline 12 & .619 & 2.381 & 78.066 & & & & & & \\
\hline 13 & .577 & 2.219 & 80.285 & & & & & & \\
\hline 14 & .543 & 2.088 & 82.373 & & & & & & \\
\hline 15 & .510 & 1.960 & 84.333 & & & & & & \\
\hline 16 & .485 & 1.865 & 86.198 & & & & & & \\
\hline 17 & .449 & 1.727 & 87.925 & & & & & & \\
\hline 18 & .435 & 1.672 & 89.597 & & & & & & \\
\hline 19 & .419 & 1.610 & 91.207 & & & & & & \\
\hline 20 & .390 & 1.500 & 92.706 & & & & & & \\
\hline 21 & .372 & 1.432 & 94.138 & & & & & & \\
\hline 22 & .356 & 1.371 & 95.509 & & & & & & \\
\hline 23 & .334 & 1.287 & 96.796 & & & & & & \\
\hline 24 & .310 & 1.192 & 97.988 & & & & & & \\
\hline 25 & .283 & 1.090 & 99.078 & & & & & & \\
\hline 26 & .240 & .922 & 100.000 & & & & & & \\
\hline
\end{tabular}


Table 6.3. Rotated Component Matrix (a)

\begin{tabular}{|c|c|c|c|c|c|c|}
\hline & \multicolumn{6}{|c|}{ Component } \\
\hline & 1 & 2 & 3 & 4 & 5 & 6 \\
\hline Adequate No. of branches & .321 & .148 & .739 & .105 & .030 & -.057 \\
\hline Trained and well-informed agents & .648 & .081 & .217 & .178 & .209 & .318 \\
\hline Approaching from customer's point of view & .698 & .168 & .165 & .209 & .225 & -.044 \\
\hline Accessible location of the branch & .405 & .256 & .472 & .247 & .077 & .213 \\
\hline Staff dependable in handling customer's problems & .322 & .100 & .753 & .255 & .270 & .190 \\
\hline Good ambience of the branch & .247 & .108 & .358 & .723 & .333 & .017 \\
\hline Efficient Staff & .197 & .128 & .699 & .215 & .322 & .040 \\
\hline Easy access to information & .199 & .164 & .735 & .111 & .123 & .125 \\
\hline Provision of Flexible payment schedule & .437 & .680 & .300 & .136 & .243 & .267 \\
\hline Innovativeness in introducing new products & .422 & .127 & .173 & .120 & .628 & .029 \\
\hline Possessing good certification and credentials & .232 & .172 & .118 & .753 & .107 & -.059 \\
\hline Courteous Agents & .249 & .192 & .204 & .225 & .640 & .151 \\
\hline Value for money & .243 & .115 & .342 & .060 & 644 & -.073 \\
\hline Availability of flexible product solution & .299 & .644 & .192 & .270 & .137 & .172 \\
\hline Provisions for Convertibility of products & .299 & .705 & .011 & .094 & .313 & .274 \\
\hline Supplementary services & .143 & .779 & .240 & .187 & .034 & .247 \\
\hline Prompt \& Efficient Grievance handling mechanism & .228 & .246 & .777 & .166 & .186 & .086 \\
\hline $\begin{array}{l}\text { Simple \& Less time consuming Procedure for purchasing a } \\
\text { policy }\end{array}$ & .206 & .298 & .242 & .294 & .696 & -.071 \\
\hline Trusting agents when explaining policies & .667 & .389 & .159 & .352 & .333 & -.204 \\
\hline Financially stable company & .054 & .187 & .331 & .283 & .707 & .004 \\
\hline Clarity in explaining policy's terms and conditions & .665 & .179 & .290 & .249 & .165 & .085 \\
\hline Easy online transaction & .158 & .261 & .086 & .074 & -.048 & .638 \\
\hline Complaint handling should be prompt, online & .209 & -.252 & .041 & .104 & -.050 & .753 \\
\hline Proactive information through e-mail or SMS & -.006 & .192 & .067 & .272 & .120 & .695 \\
\hline Prompt and hassle free claims settlement & .122 & .249 & .660 & .141 & .159 & -.101 \\
\hline Understanding intimately specific needs & .737 & .072 & -.042 & .318 & .368 & -.025 \\
\hline
\end{tabular}

Table 7. Gap Analysis of Service Quality Dimensions in Life Insurance Industry

\begin{tabular}{|l|c|r|r|r|r|r|}
\hline \multicolumn{1}{|c|}{ Dimension } & $\begin{array}{c}\text { Expectations } \\
\text {-Mean }\end{array}$ & $\begin{array}{c}\text { Expectations-St } \\
\text {. Dev. }\end{array}$ & $\begin{array}{c}\text { Perceptions-Me } \\
\text { an }\end{array}$ & $\begin{array}{c}\text { Perceptions-St. } \\
\text { Dev }\end{array}$ & $\begin{array}{c}\text { Gap } \\
\text { scores }\end{array}$ & $\begin{array}{c}\text { Sig } \\
\text { Tangibles }\end{array}$ \\
\hline Personalized financial planning & 4.5433 & .7443 & 3.5101 & .6453 & -1.0332 & .000 \\
\hline Corporate Image & 4.6308 & 1.1356 & 3.3888 & .9986 & -1.242 & .000 \\
\hline Technology & 4.5608 & .7725 & 3.4387 & .6654 & -1.1221 & .000 \\
\hline Competence & 4.4712 & .7881 & 3.5565 & .7003 & -0.9147 & .000 \\
\hline Assurance & 4.6341 & .9962 & 3.3169 & .8012 & -1.3172 & .000 \\
\hline
\end{tabular}




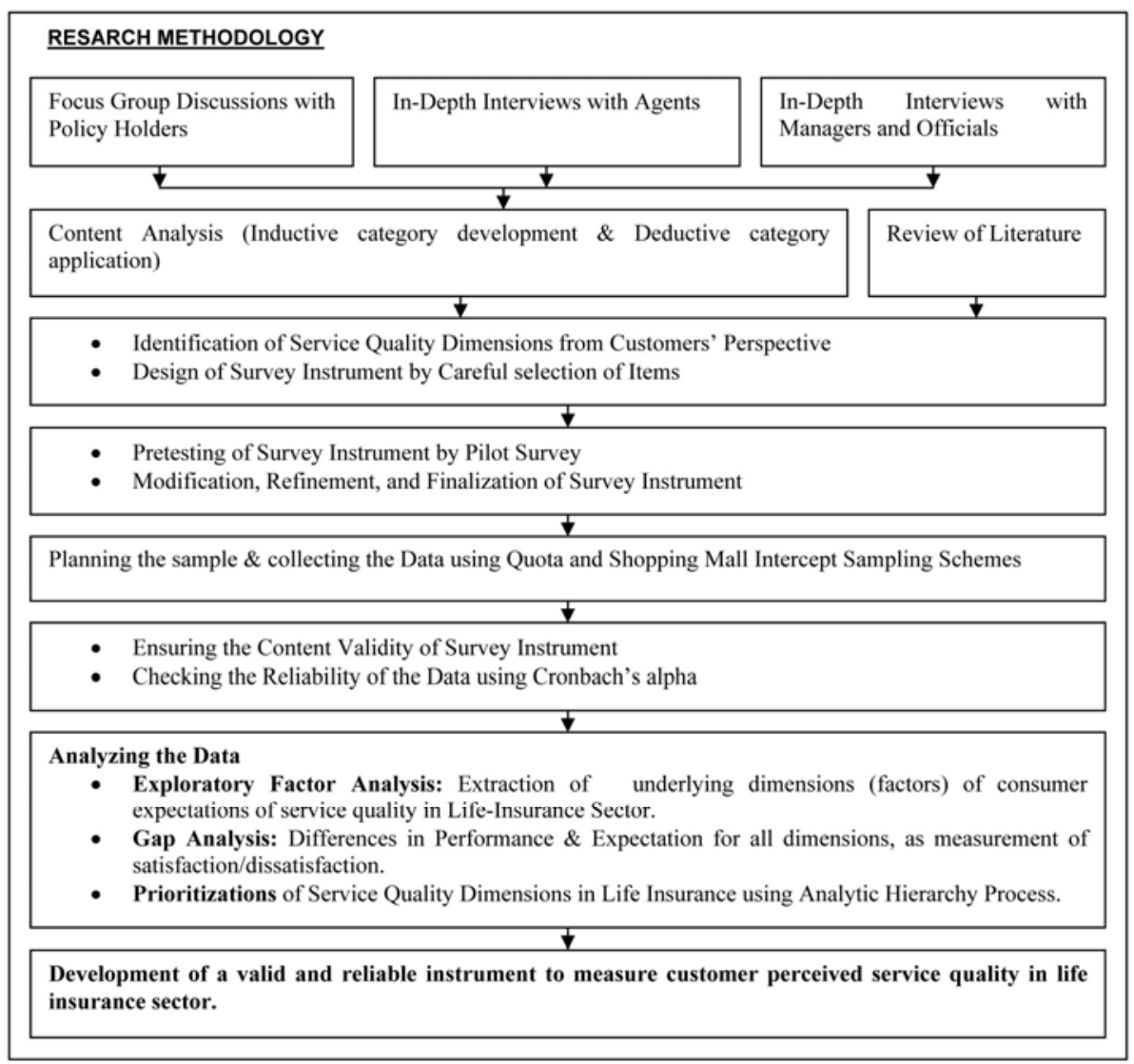

Figure 1. Research Methodology

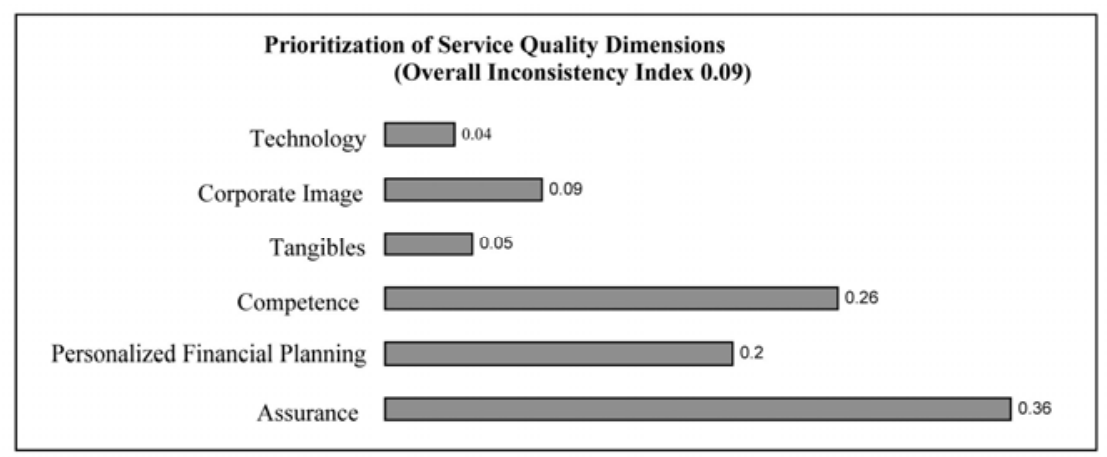

Figure 2. Relative Importance of service quality dimensions in Life Insurance Industry:

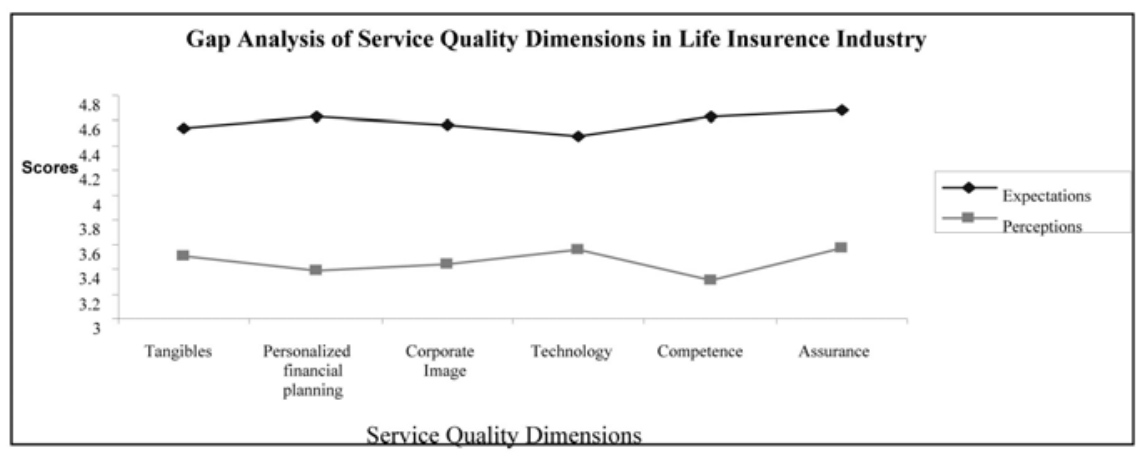

Figure3. Gap analysis of Service Quality Dimensions 